\title{
Religiosity and Moral Competence: A Study of Malaysia's Accounting Students
}

\author{
Umaru Mustapha ZUBAIRU1', Chetubo Kuta DAUDA', Isah Imam PAIKO', \\ Olalekan Busra SAKARIYAU ${ }^{1}$
}

\section{ARTICLE INFO \\ Article History: \\ Received 01.10.2016 \\ Received in revised form \\ 27.11.2106. Accepted \\ .Available online 01.01.2017}

\begin{abstract}
In the earliest part of the twenty-first century, the world was rocked by several financial scandals; from Enron to WorldCom; Tyco to Parmalat; Arthur Andersen to Shell, and more recently, the global financial crisis; these scandals directed the world's attention towards the seemingly ever-growing moral malaise amongst accountants and business people. In order to address this alarming increase in unethical and immoral behaviours among accountants and business people in Malaysia, the government mandated the teaching of Islamic and Moral studies at all levels of education. The underlying assumption was that an increased level of religiosity would translate into higher levels of moral competency. This paper sought to assess the effectiveness of Malaysia's educational policy of mandatory Islamic studies in developing the moral competencies of the country's future Muslim accountants. This was achieved by determining whether a positive relationship existed between the religiosity and moral competencies of Muslim accounting students enrolled at the International Islamic University Malaysia (IIUM). The results revealed that although a small and positive correlation existed between the students' religiosity and moral competencies, a knowledge gap existed preventing them from being able to fully apply Islamic principles in an accounting context.
\end{abstract}

(C) 2017 IJERE. All rights reserved

Keywords:

Religiosity, Moral competence, Accounting students, Islamic university

\section{INTRODUCTION}

In the earliest part of the twenty-first century, the world was rocked by several financial scandals; from Enron to WorldCom; Tyco to Parmalat; Arthur Andersen to Shell, and more recently, the global financial crisis (Bayou et al., 2011); these scandals directed the world's attention towards the seemingly ever-growing moral malaise amongst accountants and business people.

The concern about the rampant increase in immoral practices of accountants and business people was not restricted only to America and Europe; there was also concern in Malaysia. Abu Bakar et al. (2010) explained that as early as the 1980s, public confidence in the Malaysian accounting profession took a battering due to collapse of organizations like Bank Bumiputra and Pan-Electric. In the 90s, there was a very noticeable increase in white-collar crimes involving accounting companies, some of which were sued by their clients such as Johari Abas, and Anor, David Low See Keat and Orsants (Abu Bakar et al., 2010). In recent times, concern has grown in the society regarding the alarming increase in the unethical and immoral practices amongst managers in Malaysia (Abu Bakar et al., 2010; Yunus and Abdul Rashid, 2011; Eid, 2012).

In order to address this alarming increase in unethical and immoral behaviours among business people in Malaysia, the government focused on the educational sector as a viable mechanism. This is evidenced by Malaysia's National Philosophy of Education (NPE), which emphasizes the development of individuals in a holistic manner. The objective is to produce students that are balanced intellectually, spiritually, emotionally and physically. To achieve this, Islamic Studies and Moral Studies have been made compulsory at all levels of education in Malaysia; Islamic studies for Muslims, and Moral studies for nonMuslims (Ali et al., 2010). The underlying assumption of this policy was that Islamic studies would enhance the religiosity of Muslim students, which in-turn would enable them to act in line with Islamic principles in the course of their daily lives. In other words, the Malaysian government believed that religiosity was positively associated with moral competence.

This paper sought to assess the effectiveness of Malaysia's educational policy of mandatory Islamic studies in developing the moral competencies of the country's future Muslim accountants. This was achieved by conducting a survey of Muslim accounting students enrolled at the International Islamic University Malaysia (IIUM). An ethical scenario-based instrument developed by the author in collaboration with five 
Islamic accounting and Fiqh Muamalat scholars (Law of Islamic business transactions) was utilized to measure the religiosity and moral competencies of these students, and statistical analysis were conducted to determine if a positive association existed between student religiosity and moral competence.

This study had two key concepts: religiosity and moral competence. In the context of this study, religiosity is defined as the strength of a person's commitment to the precepts of Islam; in order words, the strength of a Muslim's faith. In conceptualizing religiosity for this study, two issues were considered from an Islamic perspective: Firstly, what factors shape a students' religiosity before he or she enrolled into university? Secondly, what is the most external evidence of a Muslim's religiosity? In dealing with the first issue, reference is made to the following hadith which explains that a child's home environment impacts his or her religiosity: Allah's Messenger (PBUH) said, "No child is born except on Al-Fitra (Islam) and then his parents make him Jewish, Christian or Magian, as an animal produces a perfect young animal: do you see any part of its body amputated?" Then he read, 'So direct your face toward the religion, inclining to truth. [Adhere to] the fitrah of Allah upon which He has created [all] people. No change should there be in the creation of Allah. That is the correct religion, but most of the people do not know (30.30)'. (Sahih al-Bukhari, Book 65, Hadith 4822). The importance the parents place on the precepts of Islam as a way of life will affect the child's religiosity; if religion is very important in the household, the child will be very religious. If religion is of no importance, then the child will not be very religious.

The second environment which would impact on the student's religiosity would be the choice of secondary school attended. In Malaysia, students have two choices as regards secondary schools: religious or secular. Shah's (2004) study of 100 Malay secondary school students drawn equally from religious and secular schools revealed that students from religious schools displayed a higher level of religiosity than those in secular schools. Additionally, Saat et al.'s (2010) study revealed that Malaysian students who attended religious secondary schools possessed "strong religious views and [were] inclined to have a close relationship with God" (Saat et al., 2010, p17). It can thus be concluded that the accounting students who attended religious secondary schools would be more religious than those that attended secular secondary schools. Importance of religion in the student's family and choice of secondary school thus served as the two factors that determined the student's religiosity before enrolment into the university.

Regarding the second issue addressing the most visible expression of a Muslim's religiosity, the following hadith provides crucial guidance: It was narrated that Jabir bin 'Abdullah said: "The Messenger of Allah (PBUH) said: 'Between a person and Kufr (disbelief) is abandoning the prayer.'" (Sunan Ibn Majah, Book 5, Hadith 1131). For the Muslim, performing the five obligatory prayers is the clearest expression of his or her religiosity. Additionally, for the male Muslim, performing these prayers in the mosque is obligatory and thus an important evidence of his religiosity. This obligation is evidenced in the following hadith: it is narrated from Abu Hurayrah that the Messenger of Allaah (PBUH) said: "By the One in Whose hand is my soul, I had thought of ordering that wood be gathered, then I would command the call to prayer to be given, and I would appoint a man to lead the people in prayer, then I would go to men [who do not attend the congregational prayer] and burn their houses down around them. By the One in Whose hand is my soul, if anyone of you had known that he would receive a bone covered with meat or two (small) pieces of meat in a sheep's foot, he would come for 'Isha' prayer." (Sahih Bukhari, Hadith 7224). The famous Islamic scholar Ibn Al-Mundhir explained the hadith as follows: "The fact that he (PBUH) was thinking of burning down the houses of people who did not attend the prayer is the clearest evidence that attending prayer in congregation is obligatory, because it would not be permissible for the Prophet (PBUH) to do this with regard to something that was mustahabb (recommended) and not obligatory" (Ruling for prayer in congregation for men, n.d., emphasis added). Interestingly, the most common proxy for religiosity in moral competence scholarship has been frequency of religious attendance (Levin \& Markides, 1986; Kahan, 2002; Hilary \& Hui, 2009; Yeşilada, et al., 2009; Lim \& MacGregor, 2012; Patton et al., 2015).

To conclude, religiosity as conceptualized for this study had two broad components: 1 . Factors that shaped the student's religiosity before enrollment in university (a. Importance of religion to student's family and b. Secondary school attended [religious versus secular]); 2. External expression of religiosity (1. Performance of five daily prayers and 2 . Praying in the mosque). 
In this study, a morally competent Muslim accountant was defined as one who has the ability to make moral decisions in line with the commands of Allah in the Noble Qur'an, and in accordance with the Sunnah of the Noble Prophet Muhammad (PBUH), in discharging his or her duties as an accountant.

In Islam, this concept of moral competence is made up of two separate but interdependent parts: 1) knowing the right thing to do (moral action), and 2) doing the right thing for Allah's sake alone (moral intention). In the sight of Almighty Allah, a moral action is only acceptable if the moral intention is solely for His pleasure. The Blessed Prophet Muhammad (PBUH) explains this very important point in the famous hadith narrated by Umar bin Al-Khattab: The Messenger of Allah (PBUH) said, "The deeds are considered by the intentions, and a person will get the reward according to his intention. So whoever emigrated for Allah and His Messenger, his emigration will be for Allah and His Messenger; and whoever emigrated for worldly benefits or for a woman to marry, his emigration would be for what he emigrated for" (Riyad as-Salihin, Book 1, Hadith 1). This is a very crucial concept which this study took into consideration when assessing the moral competencies of Malaysia's future Muslim accountants. Figure 1 below illustrates the above mentioned conceptualization of moral competence.

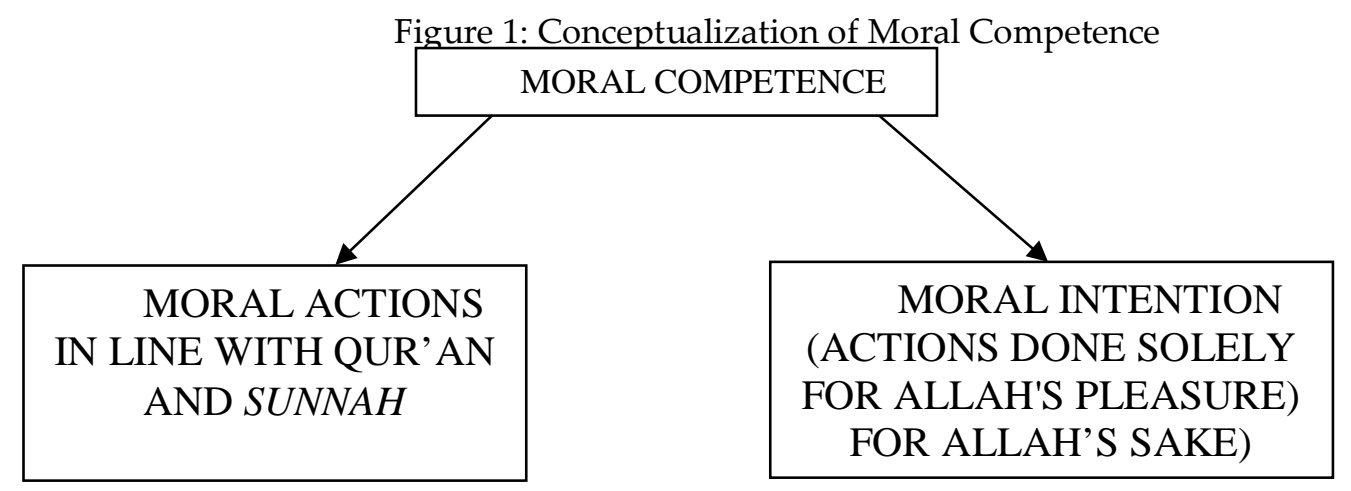

In Islam, religiosity and moral competence are intimately related; in fact, one cannot exist without the other. If religiosity is the strength of a Muslim's faith, then moral competence is the evidence of that faith. In the Noble Quran, these two concepts are mentioned together in over 60 verses: "those who believe and do righteous deeds" (Al-Baqara: 25, 82, 277; Aal-i-Imran: 57; An-Nisa: 57); "believe" referring to a person's religiosity and "righteous deeds" referring to a person's moral competence.

A person who claims to be religious but does not produce the fruit of righteousness has been described in the Noble Quran as "a donkey which carries huge burdens of books (but understands nothing from them)..." (Al-Jummu'a: 5). True salvation can only attained by a Muslim that possesses sincere religiosity backed up by sincere moral competence: "By time, Indeed, mankind is in loss, except those who believe, and do righteous deeds, and counsel each other unto the truth, and counsel each other to be steadfast" (Al-Asr: 1-3).

The rest of the paper proceeds as follows: Firstly, the research paradigm adopted in this study is describe so the reader can better understand the context of the paper. Secondly, a literature review of past studies that have explored the relationship between religiosity and moral competence is provided. The study's conceptual framework and research methodology form the next two sections of the paper. The study's research findings and a discussion of these findings follow, and the paper ends with a conclusion.

\section{LITERATURE REVIEW: STUDENT RELIGIOSITY AND MORAL COMPETENCE}

The papers reviewed all sought to investigate the relationship between religiosity of students and their moral competencies. The expected relationship was that the higher a student's religiosity, the higher his or her level of moral competence. The majority of the papers reviewed found support for the expected positive relationship between student religiosity and moral competence; only two of the papers reviewed failed to find support for the expected positive relationships. The studies reviewed are presented in Table 1 below, classified in terms of those that either found support or no support for the expected positive relationship between student religiosity and moral competence: 
Table 1: Positive relationship between student religiosity and moral competence

\begin{tabular}{llll}
\hline \multicolumn{1}{c}{ Support } & No & No support & No \\
\hline & & \\
$\begin{array}{l}\text { Conroy \& Emerson, 2004; Shah, 2004; Albaum \& Peterson, 2006; } \\
\text { Keller et al., 2007; Kurpis et al., 2007; Muhamad, 2009; Alleyne \& }\end{array}$ & $\begin{array}{l}\text { Burks \& } \\
\text { Persaud, 2012; Stapleton, 2013; Szekely et al., 2015 }\end{array}$ & $\begin{array}{l}\text { Sellani, 2008; } \\
\text { Lyons (2013) }\end{array}$
\end{tabular}

Conroy \& Emerson (2004) surveyed students from various fields of study enrolled at two American universities; one public university and one private religious university. Frequency of church attendance was used as a proxy for the students' religiosity, while moral competence was measured using an instrument with 25 ethical scenarios. Their findings showed that student religiosity was a significant predictor of moral competence.

Albaum and Peterson (2006) study also took place in America, but their focus was on business students. Nearly 3000 business students enrolled in 58 universities were surveyed; Students' religiosity was determined by the strength of their religious identification and their moral competencies were measured based on their attitudes towards certain ethical dilemmas. Student religiosity was found to be positively associated with moral competence. Kurpis et al. (2007) also surveyed American business students and found a similar positive association between student religiosity and moral competence; Strength of student religious identification also served as a proxy for student religiosity, whilst moral competence was measured using business scenarios developed by Dornoff and Tankersly (1975).

Keller et al.'s 2007 American study was of particular interest to this study because its focus was accounting students. Like Albaum and Peterson (2006), students' religiosity was determined by asking them how important religion was in their lives, whilst their moral competencies were measured using ethical scenarios. Alleyne and Persaud (2012) also focused on accounting students, but unlike Keller et al. (2007), these students were enrolled in a university in Barbados. The same proxy utilized by Albaum \& Peterson (2006), Keller et al. (2007) and Kurpis et al. (2007) for student religiosity was also utilized in this study; student's moral competencies was measured using ethical scenarios adopted from Landry et al. (2004). A positive relationship between student religiosity and moral competence was also found.

Stapleton's (2013) study shifted focus from the Americas to a European context by surveying 3rdyear Education majors studying in an Irish university. The students' religiosity was measured using the Santa Clara Strength of Religious Faith Questionnaire (SCSRFQ), whilst their moral competencies was measured using the Defining Issues Test (DIT). Despite the difference in proxies for religiosity and moral competence, the result was the same as for all the studies discussed above, with a positive association discovered between student religiosity and moral competence. Szekely et al. (2015) study also took place in Europe, specifically Romania, and found a positive association between student religiosity and moral competence. Emulating Conroy \& Emerson's (2004) study, students from various fields of study in the chosen university were surveyed; their religiosity was determined using a measure developed by Joseph and DiDuca (2007) specifically for a Christian population whilst their moral competencies was measured using moral dilemmas.

The studies of Burks and Sellaini (2008) and Lyons (2013) were the only ones that did not find support for the expected positive relationship between student religiosity and moral competence. Burks and Sellaini (2008) surveyed final-year accounting and business students enrolled in three American universities. The students' religiosity was measured using Allport and Ross' (1967) Religious orientation scale, whilst their moral competencies were measured using the shorter version of the DIT called the DIT-2. The results of the study revealed that religiosity did not impact the moral competencies of either accounting or business studies. Lyons' (2013) study was also based in America and did not find a positive association between student religiosity and moral competence; students' religiosity was measured using Religiosity Measures Questionnaire (RMQ) developed by Rohrbaugh and Jessor (1975) whilst their moral competencies was measured using the HahmBeller Values Choice Inventory (HBVCI), which consists of 16 moral dilemma items common to sporting activities. The findings of these two studies go against the grain of the findings of the other American-based studies already reviewed. Burks and Sellaini (2008) explain it is not surprising that 
some studies do not find a positive relationship between student religiosity and moral competence because different studies use different proxies to measure religiosity, different instruments to measure moral competency and survey different populations.

Shah (2004) and Muhamad (2009) are the last two papers reviewed in this section. These studies are reviewed last because they most closely resembled this study by exclusively surveying Muslim students in Malaysia. Shah (2004) surveyed 100 Malay Muslim secondary school students drawn equally from religious and secular schools. The choice of secondary school (religious vs secular) served as a proxy for religiosity, whilst their moral competencies were determined using a measure developed by the author in collaboration with Islamic scholars. The findings of the study revealed that students from religious schools displayed a higher level of religiosity than those in secular schools. Muhamad (2009) surveyed 429 final-year students from the Faculty of Business and Accountancy and Academy of Islamic Studies at the University of Malaya. Students' religiosity was measured using an author-developed measure, whilst their moral competencies were measured using ethical scenarios adopted from Hussin (2001). Like Shah (2004), this study also found that religiosity was strongly associated with the moral competencies of Muslim Malaysian students.

As can be observed from the review of studies above, several proxies for student religiosity and different measures of moral competencies have been adopted in various studies. What is common amongst all these studies is the use of Likert-scales to measure the moral competencies of these students. The problem with the Likert scale is that it fails to measure the true attitudes of respondents. Also, it is not unlikely that people's answers will be influenced by previous questions, or will heavily concentrate on one response side (agree/disagree) (Brunier and Graydon, 1996; LaMarca, 2011; Mukhtar, 2012). These weaknesses of the Likert scale might prevent a researcher from obtaining quality information about the moral competence of participants.

On the other hand, open-ended questions would be a higher quality alternative to the Likert scale, when measuring the moral competence of accounting students. This is because they allow participants of a study to provide more information about their feelings, motivations, attitudes and understanding of a subject, thus giving the researcher a better ability to understand the participants' true feelings on an issue. Open-ended questions also minimize two types of response error: firstly, respondents are unlikely to forget the answers they have to choose from if they are given the chance to respond freely, and secondly, openended questions simply do not allow respondents to disregard reading the questions and just concentrate on one response side as is the case with the Likert scale (Nortje 2010; Neluvhalani, 2012; Trott, 2012;) These advantages of open-ended questions are well suited for moral competence research as they would reveal how well a participant understands an ethical dilemma, and whether or not he or she possesses the moral competence to resolve the dilemma. This study sought to avoid the major problems of the Likert scale by adopting open-ended questions in order to ascertain the moral competence of Muslim accounting students enrolled in IIUM. This section of the paper present the study's research design and methodology. Firstly, an overview of IIUM is provided, with particular emphasis on the accounting department from which the students that participated in the study belong to. Secondly, the steps followed to develop a profile of a morally competent Muslim accountant are presented. Thirdly, the steps followed to develop the instrument to measure the moral competencies of Muslim accounting students is presented. Finally, the actual procedure adopted for measuring the moral competencies of the specified students is discussed.

\section{An overview of the International Islamic University Malaysia (IIUM):}

IIUM was established on 23rd May, 1983 based on the philosophy that all fields of knowledge should lead toward the recognition of, and submission to, the fact that Almighty Allah is the only one worthy of worship and is the Absolute Creator and Master of the universe. IIUM has a four-pronged mission of Integration, Islamization, Internationalization and Comprehensive Excellence (International Islamic University, 2014). The university provides bachelors' degrees, masters' degrees and doctorate degrees in its 13 faculties called "kulliyyahs". Of particular interest to this study was IIUM's undergraduate accounting program which is accredited by the Malaysian Institute of Accountants (MIA). MIA accreditation of an accounting programme is very important as only students that graduate from such programmes can legally call themselves "accountants" in Malaysia (Malaysian Institute of Accountants, 2014). IIUM's accounting programme claims to integrate Islamic principles with contemporary accounting knowledge. In order to 
graduate, students are required to complete a minimum of 134 hours of a combination of universityrequired, kulliyyah-required and departmental courses which includes practical training; 3 of the universityrequired courses have Islamic ethical content (a. Islamic Worldview, b. Islam, Knowledge and Civilization and c. Ethics and Fiqh for Everyday Life); 4 of the kulliyyah-required courses have Islamic ethical content. In addition, a recent Islamization initiative has mandated that ethical and Islamic content be integrated in all courses (International Islamic University, 2014). At the time this study, IIUM department of accounting had 28 academic staff and 552 undergraduate students enrolled.

At IIUM, first-year students are all required to take general courses. They only select their major in their 2nd year of study. This is why this study excluded these students in its sample. 2nd-year, 3rd-year and final-year accounting students served as the sample of this study.

\section{Developing the Profile of the morally competent Muslim accountant}

This section described the process adopted in order to develop the profile of a morally competent Muslim accountant. The profile was developed from the perspective of the Muslim accounting graduate, and was divided into two components: 1) Finding the "right" job, and 2) Following an Islamic "code of conduct". A discussion of these two components is presented below

1: Finding the "right" job

Nu'man b. Bashir (Allah be pleased with him) reported: I heard Allah's Messenger (PBUH) as having said this (and $N u^{\prime}$ man) pointed towards his ears with his fingers): What is lawful is evident and what is unlawful is evident, and in between them are the things doubtful which many people do not know. So he who guards against doubtful things keeps his religion and honor blameless, and he who indulges in doubtful things indulges in fact in unlawful things, just as a shepherd who pastures his animals round a preserve will soon pasture them in it. Beware, every king has a preserve, and the things God has declared unlawful are His preserves. Beware, in the body there is a piece of flesh; if it is sound, the whole body is sound and if it is corrupt the whole body is corrupt, and hearken it is the heart (Sahih Muslim 1599a, Book 22, Hadith 133).

For the Muslim accounting graduate, the first challenge that faces him or her is finding the "right" job. The "right" job is one where all activities are in line with the Qur' an and Sunnah. As the hadith above teaches us, the permissible jobs are clear and the prohibited jobs are clear, and the morally competent Muslim accountant must be able to make this distinction. The permissible activities are numerous in number, and thus the Muslim accountant has many options. Say, "My Lord has only forbidden immoralities what is apparent of them and what is concealed - and sin, and oppression without right, and that you associate with Allah that for which He has not sent down authority, and that you say about Allah that which you do not know"(AlAraf: 33). However, there are certain kinds of jobs the Muslim accountant has to avoid because the activities that they engage in are incompatible with the commands of Almighty Allah. ... And cooperate in righteousness and piety, but do not cooperate in sin and aggression. And fear Allah; indeed, Allah is severe in penalty (Al-Maeda: 2). Some of the most commonly known haram activities include i) dealing in interest, ii) gambling, and iii) dealing with intoxicants.

After securing a job at an Allah-approved organization, the next concern for the morally competent Muslim accountant is to fulfill his or her duties in accordance with the commands of Almighty Allah. This "Code of Conduct" represented the second component of the profile.

\section{2: Following an Islamic Code of Conduct}

As mentioned already in previous parts of this study, every act of a morally competent Muslim must be done with the objective of earning the pleasure of The Most Gracious Allah. A Muslim accountant must thus keep this critical objective in mind whilst discharging his or her duties as an accountant. The objective of this component of the profile was to develop a comprehensive Islamic code of conduct that includes all the qualities that a morally Muslim accountant must display in order to please his Creator. In order to develop this code of conduct for Muslim accountants, the study adopted a two-pronged approach.

The first prong was to adopt the code of conduct for Muslim accountants developed by the Accounting and Audit Organization for Islamic Financial Institutions (AAOIFI) as a foundation for this component of the profile. AAOIFI's code of conduct for Muslim accountants was published in 1991 and is 
derived from the Noble Qur'an and Sunnah; this made it an excellent starting point. AAOIFI's code of conduct contains five ethical principles described below:

1. Trustworthiness: The Muslim accountant should be straightforward and honest whilst discharging his duties, and must never present untruthful information.

2. Objectivity: The Muslim accountant should be fair, impartial and free from any conflict of interest.

3. Professional competence and diligence: The Muslim accountant must possess the requisite skill necessary to successfully discharge his duties.

4. Confidentiality: The Muslim accountant must never divulge information obtained about an organization during the course of discharging his or her duties without permission unless he or she is legally or professionally obliged to do so.

5. Professional conduct and technical standards: The Muslim accountant must observe the rules of professional conduct and obey the accounting and auditing standards of Shariah-compliant organizations.

The second prong was to interview and consult extensively with five Islamic scholars well versed in the Qur'an and Sunnah, particularly in the areas of "Islamic accounting" as well as "Fiqh Mu'amalat" (Laws of Islamic business transactions). These consultations established the content validity of AAOIFI's code of conduct. In addition to the five qualities listed by AAOIFI's code of conduct, the scholars suggested that three more qualities be added under the umbrella of "Faith-Driven" conduct, which are unique to the Muslim accountant. These qualities included 1) Avoiding interest, 2) Avoiding gambling, and 3) Avoiding physical contact with the opposite sex (non-mahram).

In total the developed profile of the ideal Muslim accountant had nine key qualities listed below:

1) Finding the right job 2) Trustworthiness 3) Objectivity 4) Professional competence and diligence 5) Confidentiality 6) Professional conduct and technical standards 7) Avoiding interest 8) Avoiding gambling 9) Avoiding physical contact with the opposite sex.

After the development of the two-component profile of a morally competent Muslim accountant was completed, the next step was to develop an instrument capable of effectively measuring the nine qualities contained in the profile

\section{Developing the Muslim Accountant Moral Competency Test (MAMOC)}

A collaboration with five Islamic accounting and Figh Mu'amalat scholars resulted in the development of nine interrelated ethical scenarios to measure each of the nine qualities of a morally competent Muslim accountant highlighted above. The instrument thus developed was called "The Muslim Accountant Moral Competency Test" or "MAMOC".

MAMOC had a title and three main sections: The instrument was titled "Understanding the Career Aspirations and Work-Related Decisions of Future Accountants". In order to minimize social desirability bias amongst the respondents, the study's objective was disguised by giving the instrument this neutral heading without any obvious moral overtones. The first section was a demographic section with ten items (Age, Religion, Gender, Nationality, "How often do you pray daily?", "How important is religion in your family?", Year of study, Type of secondary school attended, "How often do you visit your place of worship?" and CGPA). Four items served as a proxy for a student's religiosity, "How often do you pray daily?", "How important is religion in your family?" Type of secondary school attended and "How often do you visit your place of worship?". The second section was titled "Choosing your dream job". Here, the respondents were given a choice of five job offers from companies in different industries. Each job offer had a company description, a job description and an annual salary. This section sought to determine if the Muslim accounting students knew what the right job was from an Islamic perspective. To test this important aspect of the students' moral competencies, all the jobs offered were unacceptable from an Islamic perspective; it was expected that the morally competent student would recognize this, and consequently reject all job offers on the basis of their unacceptability Islamically. The third section was titled "Living your dream job", and contained eight ethical scenarios, with each scenario testing each of the eight qualities of a morally 
competent accountant mentioned earlier (1) Trustworthiness 2) Objectivity 3) Professional competence and diligence 4) Confidentiality 5) Professional conduct and technical standards 6) Avoiding interest 7) Avoiding gambling 8) Avoiding physical contact with the opposite sex]. The protagonist in the scenarios was a friend of the respondent, and the respondent was required to resolve the ethical dilemmas by advising his or her friend on what to do. The scenarios were structured in this way with the hope that respondents would be more honest in their answers if they were placed in an advisory capacity, rather than as the main actors in the scenarios. To conclude the instrument, the students were asked whether they would remain with the company after all the experiences contained in the previous scenarios.

The ethical scenarios contained in the instrument were then resolved by the scholars based on evidence from the Qur'an and Sunnah. Their solution served as the model answer to each scenario, and also served as a scoring guide for determining the moral competencies of the students surveyed.

A pilot study was carried out using the newly developed instrument to assess whether respondents would understand the instructions, terminology and content of the questionnaire. Additionally, the pilot study enabled the researcher to ascertain the reliability of the scoring system developed by the Islamic scholars. 1st-year Muslim students from the Economics and Management Faculty at IIUM were used to conduct the pilot study. These students were enrolled in four different sections of a Financial Accounting Fundamentals class, and were selected because they closely resembled the students selected for the actual study, final-year Muslim accounting students. 100 questionnaires were distributed, and the students were asked to carefully go through the questionnaire and ask any questions they might have as to its content. All the students stated that they clearly understood how to fill the questionnaires. The students were then told to take the questionnaires home, complete them, and bring them to the next class session. They were also told to write down how long it took them to complete the questionnaire. 33 out of the 100 distributed questionnaires were returned.

An analysis of the completed questionnaires revealed that the students did indeed understand how to fill them. They provided well-thought out and clear resolutions to the various scenarios, and followed the stated instructions very well. The fact that first-year students could understand the instructions, content and terminology of MAMOC so well provided the researchers with confidence that the actual respondents of the study, final-year accounting students at IIUM, would understand just as well.

Savulescu et al. (1999) explain that any instrument that is to be used to measure moral competence must be capable of being reliably applied by different raters. They also suggested that "naïve" raters should be utilized (naïve raters are those not involved in the development of the instrument). Following Savulescu et al.'s (1999) advice, after the pilot study was completed, the inter-rater reliability of the scoring system was assessed using the completed questionnaires from the pilot study; Inter-rater reliability is defined as the degree to which different judges or raters agree in their assessment decisions" (Phelan \& Wren, 2006). One of the researchers and one naïve rater used the model answers to assess the moral competencies of the students that participated in the pilot study. Halgren (2012) stated that Intra-Class Correlation (ICC) is the most commonly used statistical procedure to determine inter-rater reliability for studies that have two or more raters, with continuous variables. SPSS was used to calculate the instrument's inter-rater reliability using ICC. High ICC values indicate greater inter-rater reliability, with an ICC estimate of the 1 indicating perfect agreement and 0 indicating only random agreement. Negative ICC estimates indicate systematic disagreement between the raters (Halgren, 2012). After the completed pilot study questionnaires had been rated, an Intra-Class correlation coefficient of 0.943 showed that the two raters had an almost perfect agreement when assessing the moral competencies of the pilot study participants. This result proved the reliability of the model answer for assessment of students' moral competencies.

Another revelation of the pilot study was the fact that it took the students an average of thirty minutes to complete the questionnaire. This time was then used for the actual study. Finally, the pilot study revealed that the best approach for conducting the survey would be to get the students to complete the survey during class time, as opposed to letting them take it home and bringing it back during the next class session. By conducting the survey in class, the researchers were able to collect the completed questionnaires immediately, thus ensuring a much higher response rate in the actual study. 
As specified in an earlier section of this paper, moral competence (MC) from an Islamic perspective is a product of two components: moral action in line with the Qur' an and Sunnah (MA) and moral intention to please Almighty Allah alone (MI). Participating students were asked to resolve each scenario by stating the action they would advise their friend to take (MA), and providing a reason for that advice (MI). If a student's MA corresponded with the model MA, a score of 1 was given; if it did not, a score of 0 is given. The same rule applied for MI (1 for the correct reason, and 0 for incorrect reason). For each scenario, a student's MC $=$ MA ${ }^{*}$ MI. For a student to have a score for any scenario, both MA and MI must have corresponded with the model answers, otherwise he or she scored 0 for that scenario. Scores for each scenario were added to provide an overall MC score for each student; MC scores could range from a minimum of "0" to a maximum of "10".

The participating students were also assigned a "religiosity" score based on their responses to the four items in the demographic section that served as proxies for religiosity: "How often do you pray daily?", "How important is religion in your family?", Type of secondary school attended and "How often do you visit your place of worship?". For the first item, "How often do you pray daily?", the students had seven options $(0,1,2,3,4,5$, more than 5); A choice of $0-4$ was scored "0" as every Muslim is obligated to pray five times a day; A choice of "5" was scored "1", as the student had completed his obligation, whilst a choice of "more than 5" was scored "2" as it showed that the student engaged in extra prayers beyond the minimum requirement, and this is encouraged in Islam. For the second item, "How important is religion in your family?", the students had four options (Very important - scored "3", Moderately important - scored "2", Little importance - scored "1" and No importance - scored "0"). For the third item, Type of secondary school attended, students had two options (religious - scored "1" and normal (secular) - scored "0"). For the fourth item, "How often do you visit your place of worship?", only male students had a varying score as Islam only makes it obligatory for them to pray the five daily prayers in the mosque as mentioned in hadith stated in an earlier section of this study (Sahih Bukhari, hadith 7224); Female Muslims have the option of praying in the home or the mosque. Students had six options (Never, once a week, 2-4 times a week, once a day, 2-4 times a day, 5 times a day): only a selection of the last option, " 5 times a day", earned a score of "1"; any other choice was scored "0". However, all female students were scored "1" regardless of the choice they made. Religiosity scores thus could vary from a minimum of " 0 " to a maximum of "7".

\section{Measuring the moral competencies of Muslim accounting students at IIUM}

Following the approach adopted in the pilot study, all sections of a compulsory 2nd-year, 3rd-year and final-year accounting course were surveyed using MAMOC. 125 2nd-year students, 105 3rd-year students and 72 final-year students, completed the questionnaire. The relationship between the students' religiosity and their moral competencies was then determined using Spearman's Rank Order Correlation. This non-parametric technique was used instead of its parametric alternative, Pearson's product motion correlation, because the assumption of linearity was violated.

\section{RESEARCH FINDINGS AND DISCUSSION}

This section of the paper presents the research findings and their implications. The descriptive statistics of the study's respondents is presented first. The relationship between the religiosity of IIUM accounting students and their moral competencies as determined using Spearman's Rank Order Correlation is then presented.

\section{Descriptive Statistics}

Tables , 2,3 and 4 below present descriptive statistics of IIUM accounting students surveyed in this study. Table 1 shows the number of students surveyed in each year of study; 125 2nd-year students, 105 3rdyear students and 72 final-year students, for a total of 302 students. Table 2 reveals that the majority of accounting students surveyed were female, representing $68.9 \%$ of the sample, and Table 3 shows that the average age of the students was 21.93 years. 
Table 2: Number of IIUM accounting students surveyed

\begin{tabular}{cc}
\hline Year of Study & $\mathrm{N}$ \\
\hline 2 & 125 \\
3 & 105 \\
4 & 72 \\
Total & 302 \\
\hline
\end{tabular}

Table 3: Gender Distribution of students surveyed

\begin{tabular}{ccc}
\hline Gender & $\mathrm{N}$ & $\%$ \\
\hline Male & 94 & 31.1 \\
Female & 208 & 68.9 \\
Total & 302 & 100.0 \\
\hline
\end{tabular}

Table 4: Mean age of students surveyed

\begin{tabular}{ccccc}
$\mathrm{N}$ & Min(years) & Max (years) & Mean(years) & Std. Deviation \\
\hline 302 & 20 & 25 & 21.93 & 1.155 \\
\hline
\end{tabular}

Table 5 below shows the mean religiosity and moral competence scores for the 302 IIUM accounting students surveyed; 5.31 out of a maximum score of $7(75.86 \%)$ for religiosity, and 5.32 out of a maximum score of 10 (53.20\%) for moral competence. To shed more light on the implications of these scores, IIUM's grading system presented in Table 6 below is utilized. In terms of student religiosity, a percentage score of $75.86 \%$ is equivalent to a grade of "A-" which is considered "Extremely good". As for moral competence, a percentage score of $53.20 \%$ is equivalent to a "C-" grade which although considered "quite satisfactory" is considered a failing grade, as a "C" grade is the minimum passing grade.

Table 5: Religiosity and Moral Competence Scores

\begin{tabular}{llllll}
\hline & $\mathrm{N}$ & Minimum & Maximum & Mean & Std. Deviation \\
\hline RELSCORE & 302 & 1 & 7 & 5.31 & .994 \\
MCSCORE & 302 & 1 & 10 & 5.32 & 2.088 \\
\hline
\end{tabular}

Table 6: IIUM Undergraduate Grading System

\begin{tabular}{cccc}
\hline Percentage Score & Letter Grade & Quality Point Equivalent & Remark \\
\hline $85-100$ & A & 4.00 & Excellent \\
$75-84$ & A- & 3.67 & Extremely Good \\
$70-74$ & B+ & 3.33 & Very Good \\
$65-69$ & B & 3.00 & Good \\
$60-64$ & B- & 2.67 & Fairly Good \\
$55-59$ & C & 2.33 & Satisfactory \\
$50-54$ & C- & 2.00 & Quite Satisfactory \\
$45-49$ & D & 1.67 & Poor \\
$40-44$ & D- & 1.33 & Very Poor \\
$35-39$ & E & 1.00 & Extremely Poor \\
$0-34$ & F & 0.00 & Failed \\
\hline
\end{tabular}

Source: IIUM website

Determining the relationship between IIUM's accounting students' religiosity and their moral competencies

Table 7 below presents the results of Spearman's Rank Order correlation for the entire sample of IIUM accounting students surveyed. There was a small, positive correlation between the students' religiosity 
and their moral competencies [rho $=.204, \underline{\mathrm{n}}=302, \underline{\mathrm{p}}<.0005]$. However, with a coefficient of determination of $0.0416(0.204 * 0.204)$, students' religiosity moral competencies only share $4.16 \%$ of their variance. This means that there is not much overlap between these variables, as students' religiosity was only able to explain $4.16 \%$ of the variance in students' moral competency scores.

Table 7: Correlation between students' religiosities and moral competencies

\begin{tabular}{lllll}
\hline & & & RELSCORE & MCSCORE \\
\hline \multirow{4}{*}{ Spearman's rho } & & Correlation Coefficient & 1.000 & $.204^{* *}$ \\
& & &. & .000 \\
& & Sig. (2-tailed) & 302 & 302 \\
& MCSCORE & Correlation Coefficient & $.204^{* *}$ & 1.000 \\
& & Sig. (2-tailed) & .000 &. \\
& & $\mathrm{~N}$ & 302 & 302 \\
\hline
\end{tabular}

${ }^{* *}$ Correlation is significant at the 0.01 level (2-tailed).

Table 8 below presents the correlation between students' religiosity and moral competence for each year of study. The rho values reveal small, positive correlations between these two variables for each year of study, with the strongest correlation found in final-year students with Spearman's rho of 0.258 and shared variance of $6.65 \%$.

Table 8: Correlation by year of study

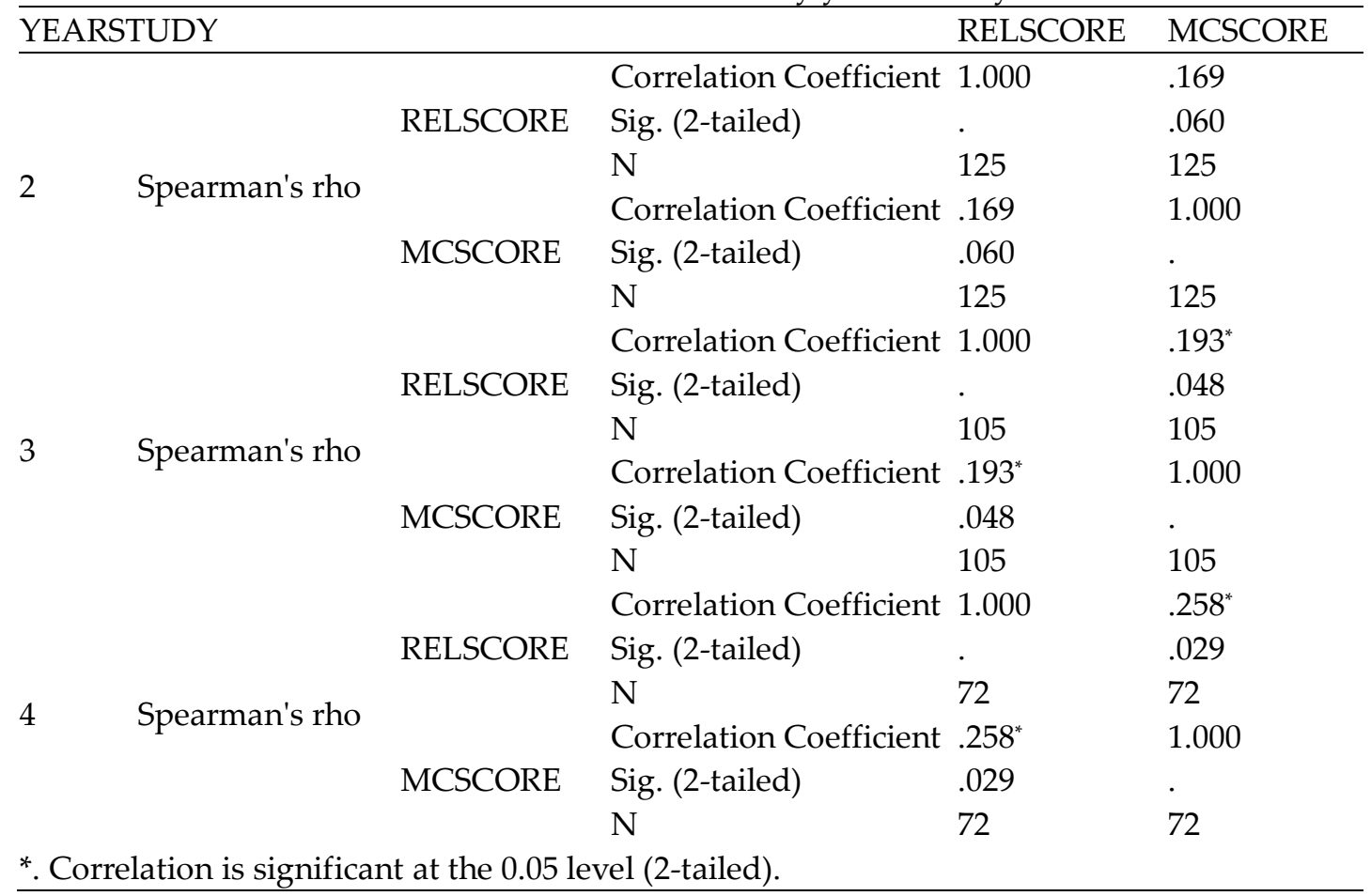

\section{Discussion}

The expected very strong and positive correlation between student religiosity and moral competence was not found amongst IIUM's accounting students; only a small, positive correlation was discovered. A likely explanation for this result is that the measure for moral competencies was specific to an accounting context. So whilst the accounting students at IIUM are very religious generally, they lacked adequate knowledge of how Islamic principles are to be applied in an accounting context. Muhamad and Ghani's (2006) study of the relationship between religiosity and moral competence amongst Malay Muslim adults adds credence to this explanation. They explained that Islamic principles only governed some aspects of the lives of Malay Muslims, particularly regarding the Islamicity of the food that they consumed. It did not influence how they 
earned a living, with many accepting dealing with interest, which is strictly forbidden in Islam, as a normal form of doing business.

IIUM's accounting department can address this gap between student religiosity and moral competence by re-evaluating the ethical content of its curriculum, and ensuring that students are taught how Islamic principles govern every aspect of the job of an accountant. It is also recommended that the issue of moral competence be given equal importance to academic achievement by the institutionalization of a measure of moral competence, which could be called the Moral Grade Point Average (MGPA), to go hand in hand with the traditional CGPA.

Regarding our second recommendation that moral competence be institutionalized, the Malaysian Ministry of Higher Education has reached the same conclusion. In 2015, the Ministry unveiled plans to institute a more holistic measure of university student performance titled "The Integrated Cumulative Grade Point Average" (iCGPA) (Ann, 2015; Khor, 2015; Tay, 2015).

The iCGPA which has been the result of six years of research and consultations will be tested in selected faculties at 5 public universities ("universiti" is "university" in the Malay language): Universiti Kebangsaan Malaysia (UKM), Universiti Teknologi Mara (UiTM), Universiti Malaysia Terengganu, Universiti Malaysia Kelantan and Universiti Malaysia Pahang. The iCGPA is intended to provide a more comprehensive measure of student performance by addressing nine specific skill sets: 1) Knowledge and understanding, 2) Practical skills, 3) Social skills and responsibilities, 4) Professional skills, ethics and values, 5) Communication skills, leadership and teamwork, 6) Problem-solving skills and scientific thinking, 7) Information management and lifelong learning, 8) Entrepreneurship and Management, and 9) Unity and patriotism (Ann, 2015; Khor, 2015; Tay, 2015). The 4th skill set encompasses the important issue of moral competence. In Islam, true salvation lies in having a strong faith in Allah which is evidenced by sincerely obeying Him in all things. This is particularly important for Muslim accountants who play a crucial role as guardians and preparers of crucial financial information which so many stakeholders rely upon. Religiosity and moral competence and thus intimately related; one cannot exist without the other.

In light of a series of financial scandals which occurred with the complicity of morally bankrupt accountants, the Malaysian government sought to improve the religiosity of future accountants by mandating Islamic and Moral studies at all levels of education. The expectation was that there would be enhanced religiosity amongst accounting students which would translate into higher levels of moral competence. This study tested this assumption amongst Muslim accounting students enrolled in IIUM. Although there was a small positive correlation between the students' religiosity and their moral competencies, the strength of correlation was not strong enough to be convincing. The cause of this weak correlation was attributed to a lack of adequate knowledge amongst the students on how to apply Islamic principles in an accounting context. It was suggested that IIUM strengthen and focus the ethical coverage of its curriculum to deal with this knowledge gap. Additionally, the Malaysian Ministry of Higher Education is taking the right steps to institutionalize the measure of moral competencies amongst university students through the introduction of the iCGPA. And those who believe and do righteous good deeds, they are dwellers of Paradise, they will dwell therein forever (Al-Baqarah: 82).

\section{REFERENCES}

Abu Bakar, N., Ismail, S., \& Mamat, S. (2010). Will graduating year accountancy students cheat in examination? A Malaysian Case. International Education Studies, 3(3), 145-152.

Accounting, Auditing, and Governance Standards for Islamic Financial Institutions, 1420H-1999, Bahrain: AAOIFI

Albaum, G., \& Peterson, R. A. (2006). Ethical attitudes of future business leaders do they vary by gender and religiosity? Business E Society, 45(3), 300-321. 
Ali, K.K., Salleh, R., \& Sabdin, M. (2010). A study on the level of ethics at a malaysian private higher learning institution: Comparison between foundation and undergraduate technical-based students. International Journal of Basic and Applied Sciences, 10(5), 35-49.

Alleyne, P., \& Persaud, N. (2012). Exploring undergraduate students' ethical perceptions in Barbados: Differences by gender, academic major and religiosity. Journal of International Education in Business, 5(1), 5-21.

Ann, H. W. (2015). ICGPA - Too little, too late? Retrieved from http://www.bfm.my/current-affairsicgpa.html

Bayou, M. E., Reinstein, A., \& Williams, P. F. (2011). To tell the truth: A discussion of issues concerning truth and ethics in accounting. Accounting, Organizations and Society, 36(2), 109-124.

Brunier, G., \& Graydon, J. (1996). A comparison of two methods of measuring fatigue in patients on chronic haemodialysis: visual analogue vs Likert scale. International Journal of Nursing Studies, 33(3), 338-348.

Burks, B. D., \& Sellani, R. J. (2008). Ethics, religiosity, and moral development of business students. Journal of Leadership, Accountability and Ethics, 49-71.

Conroy, S. J., \& Emerson, T. L. (2004). Business ethics and religion: Religiosity as a predictor of ethical awareness among students. Journal of Business Ethics, 50(4), 383-396.

Eid, M. (2012). Paula S. Tompkins: Practicing communication ethics: Development, discernment, and decision making. Journal of Business Ethics, 1-2.

Halgren, K.A. (2012). Computing inter-rater reliability for observational data: An overview and tutorial. Tutor Quants Methods Psychol., 8(1), 23-34.

Hilary, G., \& Hui, K. W. (2009). Does religion matter in corporate decision making in America? Journal of Financial Economics, 93(3), 455-473.

Kahan, D. (2002). Religiosity as a determinant of physical activity: The case of Judaism. Quest, 54(2), 97-115.

Keller, A. C., Smith, K. T., \& Smith, L. M. (2007). Do gender, educational level, religiosity, and work experience affect the ethical decision-making of US accountants? Critical Perspectives on Accounting, 18(3), 299-314.

Khor, A. (2015). Towards an integrated grading system. Retrieved from http://www.thestar.com.my/News/Education/2015/08/16/Towards-an-integrated-grading-system/

Kurpis, L. V., Beqiri, M. S., \& Helgeson, J. G. (2008). The effects of commitment to moral selfimprovement and religiosity on ethics of business students. Journal of Business Ethics, 80(3), 463.

LaMarca, N. (2011). The likert scale: Advantages and disadvantages. Retrieved from https://psyc450.wordpress.com/author/nickycole76/

Levin, J. S., \& Markides, K. S. (1986). Religious attendance and subjective health. Journal for the Scientific Study of Religion, 31-40.

Lim, C., \& MacGregor, C. A. (2012). Religion and volunteering in context disentangling the contextual effects of religion on voluntary behavior. American Sociological Review, 77(5), 747-779.

Lyons, V. L. (2013). Moral reasoning of collegiate athletes and intramural sport athletes: An investigation of the influence of religiosity, gender, and type of sport played (Doctoral dissertation, The Ohio State University).

Muhamad, R. (2009). Religiosity, ethical judgments and Malaysian Muslim students. Journal of Business Systems, Governance and Ethics, 4(1), 53-68.

Mukhtar, M.A. (2012). Likert Scale. Retrieved from http://www.scribd.com/doc/110662255/Likert-ScaleMuhammad-Amirrul-Fahmi-Bin-Mukhtar 
Neluvhalani, F. E. (2012). Barriers to teacher involvement in environmental education curriculum development in the Northern Province (Doctoral dissertation).

Nortje, M. (2010). A case study of pride and commitment in afrikaans speaking south african high school teachers (Doctoral dissertation, University of Pretoria).

Patton, E. W., Hall, K. S., \& Dalton, V. K. (2015). How does religious affiliation affect women's attitudes toward reproductive health policy? Implications for the Affordable Care Act Contraception, 91(6), 513519.

Phelan, C., \& Wren, J. (2006). Exploring reliability in academic assessment. UNI Office of Academic Assessment.

Saat, M. M., Porter, S., \& Woodbine, G. (2010). An exploratory study of the impact of Malaysian ethics education on ethical sensitivity. Journal of Business Ethics Education, 7, 39-62.

Savulescu, J., Crisp, R., Fulford, K. W., \& Hope, T. (1999). Evaluating ethics competence in medical education. Journal of Medical Ethics, 25(5), 367-374.

Shah, A. A. (2004). Self-religiosity, father's attitude and religious education in the moral behaviour of adolescents. Psychology \& Developing Societies, 16(2), 187-207.

Stapleton, M.(2013). An investigation of moral development: The effect of religiosity on Kohlbergian moral reasoning. Student Psychology Journal, 4, 95-113.

Szekely, R. D., Opre, A., \& Miu, A. C. (2015). Religiosity enhances emotion and deontological choice in moral dilemmas. Personality and Individual Differences, 79, 104-109.

Tay, E. (2015). Malaysia to roll out ICGPA programme. Retrieved from http://highered.easyuni.com/2015/08/malaysia-to-roll-ut-icgpa-programme/

Trott, D. C. (2012). Teaching spirituality and work: A praxis-based pedagogy. Management Learning. doi: $10.1177 / 1350507612456501$

Yeşilada, B., Noordijk, P., \& Webster, C. (2009). Religiosity and social values of the Cypriots. Social Compass, 56(1), 15-34.

Yunus, S., \& Abdul Rashid, M.Z. (2011). The Propensity of Applying Principled-Moral Reasoning among Undergraduate Business Students in Malaysia. Canadian Journal on Scientific and Industrial Research, 2(8), 279-289. 